\title{
Factors That Affect Consumers' Trust and Continuous Adoption of Online Financial Services
}

\author{
Shih-Ming $\mathrm{Pi}^{1}$, Hsiu-Li Liao ${ }^{1} \&$ Hui-Min Chen ${ }^{1}$ \\ ${ }^{1}$ Department of Information Management, Chung Yuan Christian University, Taoyuan, Taiwan R. O. C. \\ Correspondence: Hsiu-Li Liao, Department of Information Management, Chung Yuan Christian University, \\ Chungli, Taoyuan 32023, Taiwan R. O. C. Tel: 886-3-265-5417. E-mail: wenlly@im.cycu.edu.tw; \\ wenlly0823@hotmail.com
}

Received: November 18, 2011

Accepted: March 23, 2012

Published: May 1, 2012

doi:10.5539/ijbm.v7n9p108

URL: http://dx.doi.org/10.5539/ijbm.v7n9p108

\begin{abstract}
Trust is relatively influential factor of customer behavior in online financial services. The purpose of this study is to propose a framework of intention to continuously adopt online financial services. To test the model, partial least squares is employed to analyze data collected from 126 respondents in Taiwan. The research findings showed that: 1. website trust influences on the intention to continuous adoption of online financial services; 2 . cognitive trust of online customers influences on affective trust; 3 . factors of transaction security, website and company awareness, prior Internet experience, and navigation functions directly influence on cognitive trust of online customers, and; 4. transaction security is the only factor that influences on affective trust of online customers. This research provides a theoretical foundation for academics and also practical guidelines for service providers in dealing with the trust aspects of online financial service.
\end{abstract}

Keywords: website trust, online financial services, continuous adoption

\section{Introduction}

With the fast growth of the Internet, electronic commerce is under rapid development. From earlier electronic data interchange to the advent of the Internet, more and more people conducting making commercial activities electronically, hence the appearance of electronic commerce. Two of the main advantages of electronic commerce are to reduce the restraint of distance between products and consumers, and to curtail intermediary agents. Because of these advantages, businesses world-wide are setting up websites to provide online commercial services. While a vast of companies progressively have begun online activities, their business models do vary. Companies specialize in very different online service areas such as specialized research, data inquiry, shopping, jobs hunting, recreation, and making friends...etc. Among the online activities, online financial services offer financial transaction activity of immediateness, high-speed, and without geographic limits. For financial transaction activities, time, speed, and accuracy are crucial factors. Therefore, contemporary online financial services are to fulfill the needs of customers. However, due to the lack of confidence in electronic security measures in online financial services, customers might choose not to use or not to continuously use online financial services. This research focuses on online financial services in terms of why users trust or distrust online financial services with the implication for Taiwan's financial institutions viewing how to improve the quality of their online services. With the development of electronic commerce, financial services are in fast growth as well. While more and more transactions are made online, online financial service customers' intention towards continuous adoption is especially worthy of attention and studying.

Along with the development of online services, more and more customers are aware of the advantages and benefits offered by electronic commerce. For example, the convenience of online shopping, the easiness and diversity of products searching and transparent pricing are some examples of convenience with electronic commercial transactions. However, with online consumers increasing, how customers perceive and how much they trust the electronic websites where online transactions take place becomes an issue worth exploring. Yoon (2002) argues that trust should be given substantial weight in consideration of the virtuality (faceless and storeless) of online transactions that base their own existence on the level of customer trust. Kim, Chung and 
Lee (2011) indicate that navigation functionality and perceived security had a significantly positive effect on trust. However, they found that transaction cost had no effect on trust. Satisfaction was found to positively impact trust-which, in turn, influenced customer loyalty. Kim, Tao, Shin and Kim (2010) proposes a conceptual model that delineates the determinants of consumers' perceived security and perceived trust, as well as the effects of perceived security and perceived trust on the use of e-payment systems. Luo, Zhang and Shim (2010) examine multi-dimensional trust and multi-faceted risk perceptions in the initial adoption stage of the wireless Internet platform. Johnson and Grayson (2005) suggested that interpersonal trust in consumer-level service relationships has cognitive and affective dimensions. However, how the two types of trust affect the intention to continuously use online financial services remain un-explored.

In order to understand the current development of online financial services among Taiwan's financial institutions, we explore the users' attitude toward website trust and how trust has affect their intention to continuously use of online financial services. By offering online financial services, traditional financial institutions seek to lower operational costs, improve consumer experience, retain customers and expand their share of customer (Lichtenstein and Williamson, 2006). Thus, it would benefit the financial institutions by understanding of the key factors that influence customer's continuous use of online financial service. Research has repeatedly identified online trust as a critical factor for consumer online consumption decision (Jarvenpaa, Tractinsky and Saarinen, 1999; Teo, 2002). Our research goal is to investigate in how customers of online financial services decide their continuous use of the services with an emphasis on the mediated factor - trust. This study follows four research questions:

(1) To analyze and infer the factors (of the effects) of online financial service website trust.

(2) To investigate in the mediated effects of cognitive trust and affective trust for customers' continuous use.

(3) To develop and test an explaining model for the effects of the intention to continuous use online financial services.

(4) To provide managers of online financial websites a set of working guidelines/criteria and suggestions.

\section{Theoretical Background}

\subsection{Categories of Financial Service}

Grinder (1997) stated that the major categories of financial service are: general searches, investments, mutual funds, banking/banking services, financial planning, tax planning, insurance, financial counseling, employee benefits, and education in financial services. Ray (1996) also suggested that financial services available on the Internet included brokerage services, banking services, insurance services, accounting services, financial analyses, retirement planning, portfolio management, tax planning, loan amortizations, mutual funds, stock quotes, financial research, and financial discussion groups.

\subsection{Trust}

Trust is a critical factor that, at different points in the process of online financial services, determines the outcome of the service [Wang and Emurian, 2005; Yoon, 2002; Zeithaml, Berry, and Parasuraman, 1996). In the meantime, trust serves as glue that holds the relationship between customer and the company together. Trust, like loyalty, is specific to the relationship and not merely to a particular exchange episode (Singh and Sirdeshmukh, 2000). The higher the customers' trust toward retailers, the greater the display of customer loyalty (Liang and Wang, 2006).

\subsubsection{Cognitive Trust and Affective Trust}

Building and sustaining consumer trust on Internet present a considerable challenge for online merchants and is a research topic of increasing interest and importance (Wang and Emurian, 2005). There are two types of trust cognitive trust and affective trust (Johnson and Grayson, 2005; Marrow, Hansen and Person, 2004). Cognitive trust is knowledge-driven that a customer's confidence or willingness would rely on a service provider's competence and reliability. Affective trust is characterized by the perceived security and strengths of the relationship that the confidence one places in a partner on the basis of feelings generated by the level of care and concern the partner demonstrates. In sum, cognitive trust is objective while affective trust is a subjective process of evaluation. Moreover, Morrow et al. (2004) suggests that affective trust has a positive effect on non-financial indicators of performance while cognitive trust may have a positive effect on financial performance.

\subsubsection{Trust in Financial Service Website}

Online trust can be defined as an Internet user's psychological state of risk acceptance, based upon the positive expectations of the intentions or behaviors of an online service provider (Rousseau et al., 1998; Yoon, 2002). As 
a new form of commercial activity, online financial services involve more uncertainty and risk than traditional financial services. A consumer cannot physically check the quality of a product before making a purchase, or monitor the safety and security of sent personal and financial information through the Internet. Liang and Wang (2008) suggests that customer satisfaction cannot ensure repeated buying behaviour; only when consumers first have trust in a retailer will they show repeated buying behaviour. Trust is an especially important factor under conditions of uncertainty and risk (Lee and Turban, 2001).

Therefore, online financial service providers should take customer website trust more seriously. If customers trust the online service provider and have confidence in the reliability and integrity of the service provider, they will likely feel more at ease making transactions and disclosing personal information online. After services or transaction, the more positive toward a financial service website the customers perceive, the more possible that they will return. Such relationship will stay true for a period of time and customers might share their usage experience to their friends. Besides, in terms of the trust markers brand, tailoring and predictability were all important in finance website and more so than in health website (Wang and Emurian, 2005).

\subsection{Intention}

Trust is a key mediator and moderator of prepurchase and postpurchase processes leading to long-term loyalty (Singh and Sirdeshmukh, 2000). In fact, customer loyalty is the intention to maintain relationship with existent service providers. Zeithaml et al. (1996) proposed a model of the behavioral and financial consequences of service quality. The model separated behavioral intentions into positive intention and negative intention. The model begins with a customer's assessment of service quality and posits that when service quality assessments are high. The customer's behavioral intentions are favorable, which strengthens his or her relationship with the company. When service quality assessments are low, the customer's behavioral intentions are unfavorable and the relationship is more likely to be weakened. Behavioral intentions can be viewed as indicators that signal whether customers will remain with or defect from the company.

Regarding what to do for companies building relationship with their customers, Dayal et al. (1999) investigated more than 50 e-businesses found it can be through functional benefits, process, and relationship to build customers' trust, and argued four stages of trust building - attraction, user-driven personalization, marketer-driven personalization, and trust-based collaboration. Furthermore, Yoon (2002) researches online purchase intentions proposing the model of relations among the online consumer trust, consumer satisfaction, and purchase decision, and considering website trust and satisfaction are critical influences on whether making online purchase.

H1a: Affective trust will be positively related to intension of continuous adoption.

H1b: Cognitive trust will be positively related to intension of continuous adoption.

$\mathrm{H} 2$ : Cognitive trust will be positively related to affective trust.

\subsection{Factors Influencing Website Trust}

\subsubsection{Security}

Using security mechanisms ensure your personal information is secure online (Dayal, Landesberg and Zeisser, 1999; Tiwana, 1998], and increase online customers' trust by lowering the uncertainties associated with online transactions and augmenting perceptions of safety and security of the environment (Kong and Hung, 2006). In fact, transaction security is one of the most minding things for users when making online financial activities.

H3a: Transaction security will be positively related to cognitive trust.

H3b: Transaction security will be positively related to affective trust.

\subsubsection{Prior Internet Experience}

Many researchers consider whether information collection or purchase decision, consumer will be influenced by knowledge and experience in their shopping process (Childers, 1986; Doolin et al., 2005, Jacoby, Chestnut and Fisher, 1978). Internet shopping experience was significantly associated with attitudes to Internet shopping and intentions to shop online (Doolin et al., 2005; Vijayasarathy and Jones 2000). Koivumaki (2000) further confirmed a positive relationship between the Internet shopping experience and the amount of purchase made. Prior experience with computers influences customer's attitude toward online financial services, on the other hand, Internet experience would increase the customer's willingness of using online financial services (Floh and Treiblmaier, 2006).

H4a: Prior Internet experience will be positively related to cognitive trust. 
H4b: Prior Internet experience will be positively related to affective trust.

\subsubsection{Website and Company Awareness}

The importance of awareness is to create online trust. Websites need to gain trustworthy recognition to become reliable websites. Thus, the awareness of the name of the company operating websites should be considered as an essential ingredient for garnering trust toward online websites (Yoon, 2002).

H5a: Website and company awareness will be positively related to cognitive trust.

H5b: Website and company awareness will be positively related to affective trust.

\subsubsection{Design of Website and Interface}

The design of web interfaces that provide a satisfying experience is important; as such interfaces may encourage consumers to return to a particular website (Ballantine, 2005). Because there are many categories of financial products and services, in order to avoid straying on a website, it should be noticed the design of interfaces and whole website, including color, the type of words, the space of a web page, the website map, and so on.

H6a: Design of website and interface will be positively related to cognitive trust.

H6b: Design of website and interface will be positively related to affective trust.

\subsubsection{Navigation Functionality}

Categories of online financial services are numerous, involving in transactions about money, and lacking physical service providers. Consequently, the description and procedure of each function must be illustrated exhaustively in order to make customers feel relieved when making transactions. Yoon (2002) considered the technical expertise of a website designer, overall operational efficiency, usefulness of help functions, and the speed with which navigation is conducted online, are important measures of the effectiveness of website performance. Therefore, the effective navigation functionality must be designed in order to avoid the pitfalls to abundance of information.

H7a: Navigation Functionality will be positively related to cognitive trust.

H7b: Navigation Functionality will be positively related to affective trust.

\subsubsection{Personalization}

Each time the consumer volunteers some personal information, the marketer should be ready to reward the consumer with personalized services and richer experiences (Dayal, Landesberg, and Zeisser, 1999). In the context of the World Wide Web, personalization involves automatic changes of web pages to accommodate individual user's needs, interests, knowledge, goals, or tasks (Serino, Furner and Smatt, 2005). Personalization is a popular technique to identify with consumers and is utilized in many popular websites. Serino et al. (2005) also considered personalization may increase trusting beliefs.

H8a: Personalization will be positively related to cognitive trust.

H8b: Personalization will be positively related to affective trust.

\section{Research Methodology}

This research investigated how the website trust influences intentions to continuously adopt online financial services. According to literature review, website and company awareness, design of website and interface, transaction security, prior Internet experience, personalization, and navigation functionality, the six constructs are the variables which may affect website trust, and cognitive trust and affective trust are mediating variables. We build the research model (Figure 1) of intention to continuously adopt online financial services to investigate how these factors to influence intentions to continuous adoption.

The main method of data collection for this study is survey. The data were gathered from the survey tested by using partial least squares (PLS). The unit of analysis is the individual Internet customer with prior experiences of online financial service. In this paper, we choose online stock trading as the subjects because there are many kinds of online financial service providers exist, as we proposed.

After developing the research framework, we conducted a series of personal interviews with five online stock trading professionals in Taiwan to assess the external validity of our research model. Based on our review of the previous related literature and the comments were gathered from our interviews, we constructed our survey instrument. We used the multiple-item method in which each item was measured on a seven-point Likert scale from strong disagree to strongly agree. The initial version of our survey instrument was subsequently refined through extensive pretest with 20 academics that have significant expertise in the study of online stock trading. 
The instrument was further pilot tested with 30 online customers of a stock company in Taiwan.

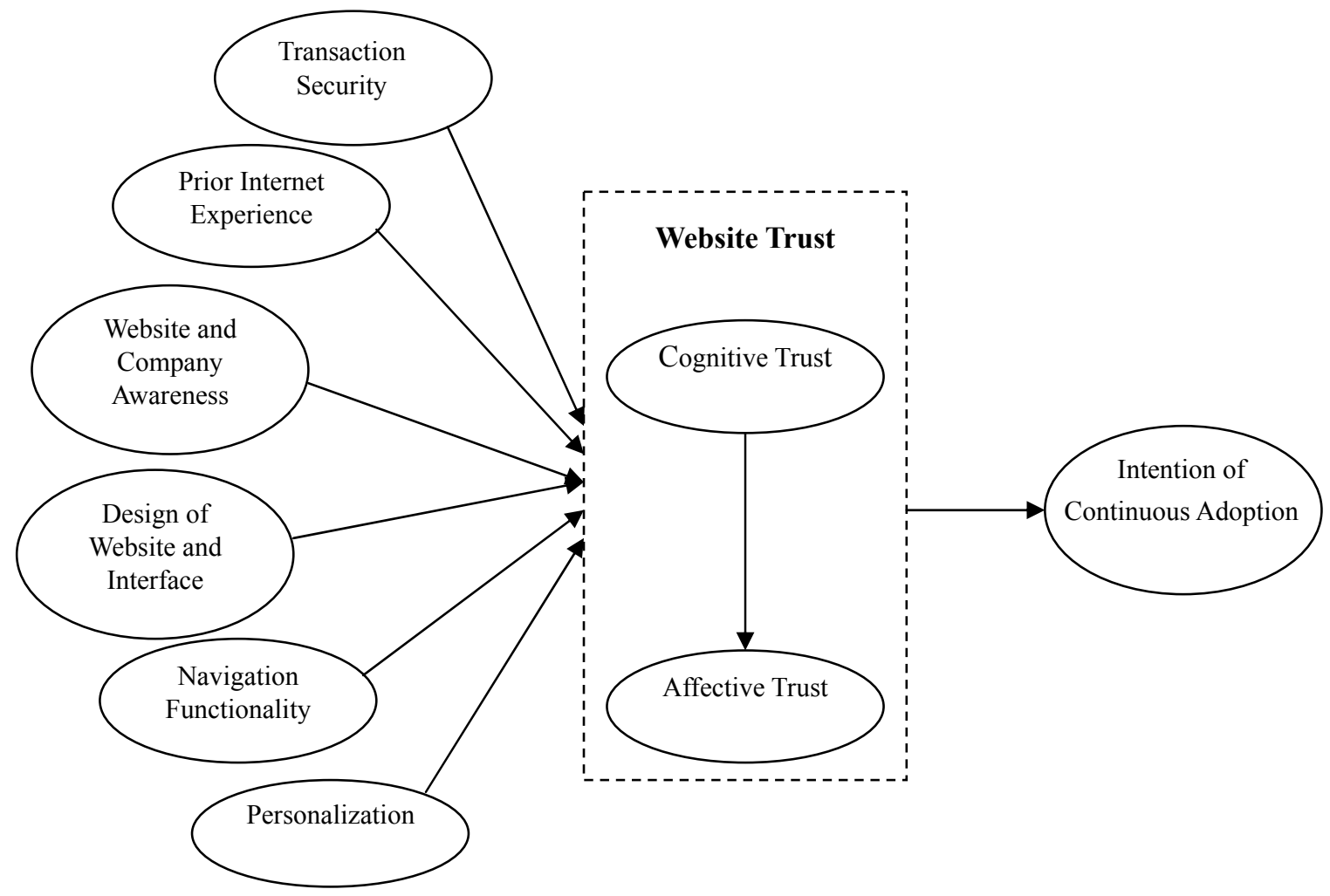

Figure 1. Research model

\section{Analysis and Findings}

For the main survey of this study, we selected top 4 companies of online stock trading as our research sites. Subjects are online customers in these companies. Besides, we also contact some members of financial student association in university as our research subjects. Due to the list of customer using online stock trading is very confidential for these companies; we asked securities professional send the questionnaire to their customers. In addition, we also ask the leader of financial student association in university to send the questionnaire to their members. From the 200 questionnaires distributed, we received 151 responses, which yielded a response rate of about 75.5 percent. Out of the 151 responses, 25 responses were eliminated from analysis because of incomplete data. The reason about high rate of invalid was because missing value of personal sensitive data. Table 1 shows the demographic information for the subjects.

Table 1. Demographic information of subjects

\begin{tabular}{llcc}
\hline & Item & $\begin{array}{c}\text { Number of Online Stock } \\
\text { Trading }\end{array}$ & $\begin{array}{c}\text { Percentage } \\
(\%)\end{array}$ \\
\hline Gender & Male & 80 & 63.5 \\
Age & Female & 46 & 36.5 \\
& Below 25 & 27 & 21.4 \\
& $26-30$ & 34 & 27.0 \\
& $31-35$ & 36 & 28.6 \\
& $36-40$ & 15 & 11.9 \\
Occupation & Above 40 & 14 & 11.2 \\
& Manager & 7 & 5.6 \\
& Professional & 5 & 4.0 \\
& General staff & 58 & 46.0 \\
& The Staff of Public Affairs & 24 & 19.0 \\
& Student & 32 & 25.4 \\
\hline
\end{tabular}




\begin{tabular}{llcr}
\hline Income (US\$, thousand) & Above 45 & 5 & 4.0 \\
& $35-45$ & 7 & 5.6 \\
& $25-35$ & 21 & 16.7 \\
& $15-25$ & 46 & 36.5 \\
& $5-15$ & 24 & 19.0 \\
Education & Below 5 & 23 & 18.3 \\
& Above Graduate & 32 & 25.4 \\
Research Sites & University or College & 87 & 69.0 \\
(Stock Company) & High School & 7 & 5.6 \\
& A & 33 & 26.2 \\
& B & 26 & 20.6 \\
Prior Experience of Internet & Below 1 year & 17 & 13.5 \\
Usage & D & 10 & 7.9 \\
& D & 40 & 31.8 \\
& 3-5 & 26 & 20.6 \\
& Above 5 year & 37 & 29.4 \\
\hline
\end{tabular}

As shown in Table 2, our composite reliability values are in the range from 0.8811 to 0.9468 , above the acceptable value. For variance extracted by measures, a score of 0.5 indicates its acceptable level. Table 2 shows that our variances extracted by measures are in the range from 0.5628 to 0.8286 , which exceeded the recommended value.

Table 2. The result of confirmatory factor analysis

\begin{tabular}{lccc}
\hline Construct & items & $\begin{array}{c}\text { Composite } \\
\text { Reliability }\end{array}$ & $\begin{array}{c}\text { Variance } \\
\text { Extracted }\end{array}$ \\
\hline $\begin{array}{l}\text { Website and Company Awareness (WEBAWA) } \\
\begin{array}{l}\text { Design of Website and Interface } \\
\text { (WEBDES) }\end{array}\end{array}$ & 6 & 0.9072 & 0.6210 \\
$\begin{array}{l}\text { Transaction Security } \\
\text { (TRASEC) }\end{array}$ & 7 & 0.8998 & 0.5628 \\
$\begin{array}{l}\text { Prior Internet Experience } \\
\text { (PRIEXP) }\end{array}$ & 4 & 0.9161 & 0.6127 \\
$\begin{array}{l}\text { Personalization } \\
\text { (PERSON) }\end{array}$ & 3 & 0.8811 & 0.7624 \\
$\begin{array}{l}\text { Navigation Functionality } \\
\text { (NAVFUN) }\end{array}$ & 3 & 0.9355 & 0.8286 \\
$\begin{array}{l}\text { Affective Trust } \\
\text { Cognitive Trust } \\
\text { (CONTRU) }\end{array}$ & 3 & 0.9280 & 0.7632 \\
$\begin{array}{l}\text { Intention to Continues Adoption } \\
\text { (CONADO) }\end{array}$ & 4 & 0.9468 & 0.8166 \\
\hline
\end{tabular}

Table 3 displays the correlations of latent variables. These values should exceed the inter-construct correlations for adequate discriminant validity. 
Table 3. Correlations of latent variables

\begin{tabular}{llllllllll}
\hline Variables & 1 & 2 & 3 & 4 & 5 & 6 & 7 & 8 & 9 \\
\hline 1.TRASEC & 1.000 & & & & & & & & \\
2.WEBDES & 0.654 & 1.000 & & & & & & & \\
3.CONADO & 0.610 & 0.587 & 1.000 & & & & & & \\
4.PRIEXP & 0.698 & 0.668 & 0.683 & 1.000 & & & & & \\
5.AFFTRU & 0.707 & 0.540 & 0.651 & 0.619 & 1.000 & & & & \\
6.NAVIGA & 0.590 & 0.607 & 0.599 & 0.695 & 0.582 & 1.000 & & & \\
7.PERSON & 0.583 & 0.509 & 0.627 & 0.712 & 0.453 & 0.605 & 1.000 & & \\
8.WEBAWA & 0.495 & 0.694 & 0.504 & 0.486 & 0.418 & 0.373 & 0.370 & 1.000 & \\
9.CONTRU & 0.722 & 0.591 & 0.763 & 0.669 & 0.716 & 0.583 & 0.478 & 0.589 & 1.000 \\
\hline
\end{tabular}

Our proposed hypotheses are tested using PLS. Figure 2 presenting the results of the PLS analysis. As proposed in Hypotheses $1 \mathrm{a}$ and $1 \mathrm{~b}$, cognitive trust $(\beta=0.608 ; \mathrm{t}=6.986 ; \mathrm{p}<0.01)$ and affective trust $(\beta=0.216 ; \mathrm{t}=2.095$; $\mathrm{p}<0.05$ ) in online stock trading are significantly related to intention of continuous adoption. The results show a significant positive relationship with intention of continuous adoption, which supported Hypothesis $1 \mathrm{a}$ and $1 \mathrm{~b}$. The test results of Hypotheses 2 shows that cognitive trust $(\beta=0.355 ; \mathrm{t}=2.802 ; \mathrm{p}<0.01)$ in online stock trading has a significant positive relationship with affective trust, indicating support for Hypotheses 2.

As proposed in Hypotheses 3a, transaction security $(\beta=0.480 ; t=6.075 ; p<0.01)$ in online stock trading is significantly related to cognitive trust. Besides, proposed in Hypotheses $3 \mathrm{~b}$, transaction security $(\beta=0.346 ; \mathrm{t}=$ $3.181 ; \mathrm{p}<0.01)$ in online stock trading is significantly related to affective trust. The results show a significant positive relationship with cognitive trust and affective trust, which support Hypothesis $3 \mathrm{a}$ and $3 \mathrm{~b}$. As proposed in Hypotheses $4 \mathrm{a}$, prior Internet experience $(\beta=0.247 ; \mathrm{t}=2.248 ; \mathrm{p}<0.05)$ is significantly related to cognitive trust. However, proposed in Hypotheses $4 \mathrm{~b}$, prior Internet experience $(\beta=0.092 ; \mathrm{t}=1.034)$ displays no significant effect on affective trust. The findings imply that the impact of prior Internet experience on affective trust is not equal to prior experience in online stock trading.

As proposed in Hypotheses 5a, website and company awareness $(\beta=0.228 ; \mathrm{t}=2.850 ; \mathrm{p}<0.01)$ in online stock trading is significantly related to cognitive trust. However, proposed in Hypotheses $5 \mathrm{~b}$, website and company awareness $(\beta=0.006 ; \mathrm{t}=0.120)$ in online stock trading displays no significant effect on affective trust. In fact, affective trust is a long-term commitment to a website, but website and company awareness is probably influence the initiate stage. So, the results show Hypotheses $5 \mathrm{a}$ is supported, but Hypotheses $5 \mathrm{~b}$ is not supported. As proposed in Hypotheses 6a, design of website and interface $(\beta=-0.071 ; \mathrm{t}=-0.094)$ displays no significant effect on cognitive trust. In addition, proposed in Hypotheses $6 \mathrm{~b}$, design of website and interface $(\beta=-0.023 ; \mathrm{t}=$ -0.345 ) displays no significant effect on affective trust. The results show Hypotheses $6 \mathrm{a}$ and $6 \mathrm{~b}$ are not supported. The reasonable explanation maybe the core value of website in online stock trading is not design of website and interface.

As proposed in Hypotheses $7 \mathrm{a}$, navigation functionality $(\beta=0.167 ; \mathrm{t}=2.125 ; \mathrm{p}<0.05)$ in online stock trading is significantly related to cognitive trust. However, proposed in Hypotheses $7 \mathrm{~b}$, navigation functionality $(\beta=0.150$; $t=1.473)$ in online stock trading displays no significant effect on affective trust. We think the reason seems the same as Hypotheses $5 \mathrm{a}$ and $5 \mathrm{~b}$, because affective trust need to long time to cultivate. So, the results show Hypotheses 7a is supported, but Hypotheses $7 \mathrm{~b}$ is not supported. Finally, in Hypothesis $8 \mathrm{a}$ and $8 \mathrm{~b}$, we investigate the influence of personalization in online stock trading on cognition trust and affective trust. The PLS results show that personalization $(\beta=-0.107 ; \mathrm{t}=-1.218)$ in online stock trading displays no significant effect on cognitive trust. Besides, personalization $(\beta=-0.073 ; \mathrm{t}=-1.128)$ in online stock trading displays no significant effect on affective trust. We think the reason seems the same as Hypotheses $6 \mathrm{a}$ and $6 \mathrm{~b}$, it means maybe transaction security is the most important factor to influence affective trust. So, the results show Hypotheses $8 \mathrm{a}$ and $8 \mathrm{~b}$ are not supported. 


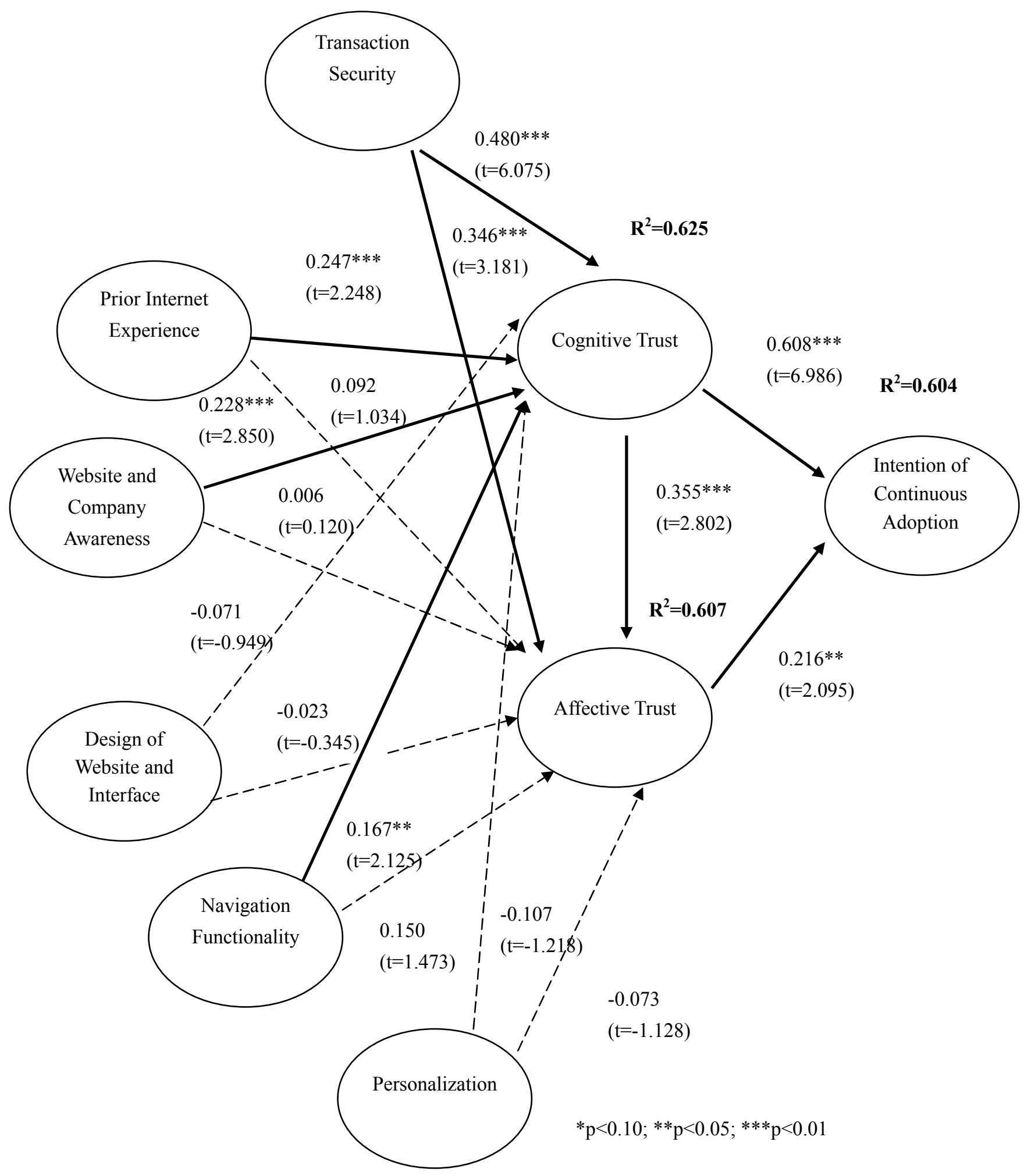

Figure 2. Results of PLS analysis

We conclude following research findings:

(1) Cognitive trust and affective trust of online customer influence on the intention to continuous adoption.

(2) Cognitive trust of online customer influence on affective trust of online customer. 
(3) Transaction security, website and company awareness, prior Internet experience, and navigation functionality influence on cognitive trust of online customer directly.

(4) Transaction security influence on affective trust of online customer directly.

These research findings show that website and company awareness influence on cognitive trust of online customer, but not influence on affective trust of online customer. We believe the main reason of this finding is the rationality of online customer. Financial companies handle affairs with customers' money. However, customers are sensitive to their money. In long term, an online stock trading website is in good reputation, but, if happening some problems, the affective trust of customers would crash. Therefore, customers always evaluate a financial company/website objectively, rather than completely believe it with affective trust.

Regard the design of website and interface, which does not influence on cognitive trust and affective trust. The reasonable explanation is that the design of general website focus on attractive or friendly, but in financial service website the importance to customers is service content and quality.

In this study, transaction security is the most important factor that significantly influence on the customers' cognitive trust and affective trust. An financial service website with security mechanisms would give their customers higher confidence and increase cognitive trust and affective trust. A financial service website with security mechanisms would give their customers higher confidence and increase cognitive trust and affective trust.

Most online customers consider navigation functionality would reduce their search cost, and it will help them find what they want quickly. According to these characteristics, it enable online customer to bring cognitive trust.

The impact of prior Internet experience is also significant on cognitive trust, but there is no impact on affective trust. The findings implied that the impact of prior Internet experience on affective trust was not equal to prior experience in online stock trading.

In our study, the most surprising result is that personalization has no impact on cognitive trust and affective trust. It is not correspond with the research result by (Johnson, and Grayson, 2005). However financial services are anyhow personalized, we find that financial service websites offer little personalized services in Taiwan. Most online customers can not realize the advantage of personalization.

Finally, the results show that cognitive trust has more impact on intention to continuously adopt online financial services than affective trust. With increasing cognitive trust, affective trust will accumulate. The research results have the same conclusion with the study of (Johnson, and Grayson, 2005).

\section{Conclusion}

On the Internet there are many unpredictable chances, as well as numerous businesses invest their money in developing online services for winning. However, we suggest a business must consider how to make website viewers become customers and continuously adopt online services, besides attracting many Internet users to visit their websites.

Therefore, this study applies Johnson, and Grayson (2005) as well as Morrow, Hansen, and Pearson (2004) proposed cognitive trust and affective trust to research the model of website trust influencing intentions to continuously adopt online financial services. We use six constructs, website and company awareness, design of website and interface, transaction security, prior Internet experience, personalization, and navigation functionality, to be the variables of influencing cognitive trust and affective trust, and furthermore we investigate the effects of two types of trust on continuously adopting online financial services.

Regarding to managerial implication, two points are listed below: (1) the cognitive trust will influence affective trust; as well as both will influence online financial service customer's continuous adoption. Therefore, to financial website service providers, in addition to pay attention to its objective attributes and establishes customers' cognitive trust, customers' affective trust and royalty to this website will be enhanced. (2) Security will also influence affective trust. To financial website service providers, security is the important base of cognitive trust and affective trust. As regards to website and company awareness, prior Internet experience, and navigation function are important factors of enhancement of cognitive trust. Overall, to financial website service providers, this has to be considered.

Some limitations are inherent in this study. First, this study collected data from customers of securities firms and college students. The representative of research questionnaires needs to be discussed further. Customers of securities firms are more specifically security aware than college students, so the further study need to 
differentiate them. The quantities of questionnaire are not too many, because people have no willingness to disclose private information. Future study could try to send more questionnaires to gain more valid responses. The results could vary with a more random sample of the population.

Second, this study mainly investigated users' behavior on financial service websites. The findings may not generalize to other contexts. However, these findings can be reasonably extended to settings such as shopping websites because of relating to online transaction. Future study could be aimed at other types of websites for understanding website users' different behavior, the level of website trust, and the difference of the factors of website trust.

Third, the factor affecting website trust, personalization, does not significantly influence on website trust. The main reason is Taiwan's online financial service website with few personalized function and services. Therefore, if financial websites providing diverse personalized services, we could have further findings.

Because of website business strategies advancing, the factors of influencing website trust will change. Future study should focus on the newest conditions of financial service websites to investigate relative factors influencing website trust. Future study also could compare with physical financial service providers and online financial service websites how to influence intentions of continuous adoption.

\section{References}

Ballantine, P. W. (2005). Effects of Interactivity and Product Information on Consumer Satisfaction in an Online Retail Setting. International Journal of Retail \& Distribution Management, 33(6/7), 461-471. http://dx.doi.org/10.1108/09590550510600870

Childers, T. L. (1986). Assessment of the Psychometric Properties of an Opinion Leadership Scale. Journal of Marketing Research, 2(3), 184-188. Retrieved from http://www.jstor.org/stable/3151666

Dayal, S., Landesberg, H., \& Zeisser, M. (1999). How to Build Trust Online. Marketing Management, 8(3), 64-69. http://dx.doi.org/10.1007/978-3-7091-6088-6_5

Doolin, B., Dillon, S., Thompson, F., \& Corner, J. L. (2005). Perceived Risk, the Internet Shopping Experience and Online Purchasing Behavior: A New Zealand Perspective. Journal of Global Information Management, 13(2), 66-88. http://dx.doi.org/10.4018/jgim.2005040104

Floh, A., \& Treiblmaier, H. (2006). What Keeps the E-Banking Customer Loyal? A Multigroup Analysis of the Moderating Role of Consumer Characteristics on E-Loyalty in the Financial Service Industry. Journal of Electronic Commerce Research, 7(2), 97-110. Retrieved from http://www.csulb.edu/journals/jecr/issues/20062/paper4.pdf

Grinder, B. (1997). An Overview for Financial Services Resources on the Internet. Financial Services Review, 6(2), 125-140. Retrieved from http://www2.stetson.edu/fsr/abstracts/vol_6_num2_p125.pdf

Jacoby, J., Chestnut, R. W., \& Fisher, W. A. (1978). A Behavioral Process Approach to Information Acquisition in Nondurable Purchasing, Journal of Marketing Research, 15(4), 532-544. Retrieved from http://www.jstor.org/stable/3150623

Jarvenpaa, S. L., Tractinsky, N., \& Saarinen, L. (1999). Consumer Trust in an Internet Store: A Cross-Cultural Validation. Journal of Computer-Mediated Communication, 5(2), 45-71. http://dx.doi.org/10.1111/j.1083-6101.1999.tb00337.x

Johnson, D., \& Grayson, K. (2005). Cognitive and Affective Trust in Service Relationships. Journal of Business Research, 58(4), 500-507. http://dx.doi.org/10.1016/S0148-2963(03)00140-1

Kim, C., Tao, W., Shin, N., \& Kim, K.S. (2010). An Empirical Study of Customers' Perceptions of Security and Trust in E-payment Systems. Electronic Commerce Research and Applications, 9(1), 84-95. http://dx.doi.org/10.1016/j.elerap.2009.04.014

Kim, M. J., Chung, N., \& Lee, C. K. (2011). The Effect of Perceived Trust on Electronic Commerce: Shopping Online for Tourism Products and Services in South Korea. Tourism Management, 32, 256-265. http://dx.doi.org/10.1016/j.tourman.2010.01.011

Koivumaki, T. (2000). Customer Satisfaction and Purchasing Behaviour in a Web-based Shopping Environment. Electronic Markets, 11(3), 148-154. http://dx.doi.org/10.1080/101967801681008022

Kong, W. C., \& Hung, Y. T. C. (2006). Modeling Initial and Repeat Online Trust in B2C E-commerce. Proceedings of the 39th Hawaii International Conference on System Sciences, 1-10. http://dx.doi.org/10.1109/HICSS.2006.354 
Lee, M. K. O., \& Turban, E. (2001). A Trust Model for Consumer Internet Shopping. International Journal of Electronic Commerce, 6(1), 75-91. $\quad$ Retrieved from http://mesharpe.metapress.com/openurl.asp?genre=article \&issn=1086-4415\&volume $=6 \&$ issue $=1 \&$ spage $=7$ 5

Liang, C. J., \& Wang, W. H. (2006). The Behavioural Sequence of the Financial Services Industry in Taiwan: Service Quality, Relationship Quality and Behavioural Loyalty. The Service Industries Journal, 26(2), 119-145. http://dx.doi.org/10.1080/02642060500369131

Liang, C. J., \& Wang, W. H. (2008). How Managers in the Financial Services Industry Ensure Financial

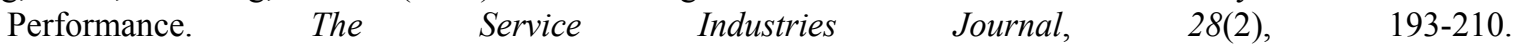
http://dx.doi.org/10.1080/02642060701842258

Liang, C. J., \& Chen, H. J. (2009). A Study of the Impacts of Website Quality on Customer Relationship Performance. Total Quality Management \& Business Excellence, 20(9), 971-996. http://dx.doi.org/10.1080/14783360903181784

Liang, C. J., Wang, W. H., \& Farquhar, J. D. (2009). The Influence of Customer Perceptions on Financial Performance in Financial Services. The International Journal of Bank Marketing, 27(2), 129-143. http://dx.doi.org/10.1108/02652320910935616

Lichtenstein, S., \& Williamson, K. (2006). Understanding Consumer Adoption of Internet Banking: An Interpretive Study in the Australian Banking Context. Journal of Electronic Commerce Research, 7(2), 50-66. Retrieved from http://www.csulb.edu/journals/jecr/issues/20062/paper1.pdf

Loonam, M., \& O’Loughlin, D. (2008). Exploring E-service Quality: a Study of Irish Online Banking. Marketing Intelligence \& Planning, 26(7), 759-784. http://dx.doi.org/10.1108/02634500810916708

Luo, X., Li, H., Zhang, J., \& Shim, J. P. (2010). Examining Multi-dimensional Trust and Multi-faceted Risk in Initial Acceptance of Emerging Technologies: An Empirical Study of Mobile Banking Services. Decision Support Systems, 49, 222-234. http://dx.doi.org/10.1016/j.dss.2010.02.008

Morrow, J. L., Hansen, M. H., \& Pearson A. W. (2004). The Cognitive and Affective Antecedents of General Trust within Cooperative Organizations. Journal of Managerial Issues, 16(1), 48-64. Retrieved from http://www.jstor.org/stable/40601183

Ray, R. (1996). An Introduction to Finance on the Internet. Financial Practice and Education, 6(2), 95-101.

Rousseau, D. M., Sitkin, S. B., Burt, R. S., \& Camerer, C. (1998). Not so Different after All: A Cross-discipline View of Trust. Academy of Management Review, 23(3), 393-404.

Serino, C. M., Furner, C. P., \& Smatt, C. (2005). Making it Personal: How Personalization Affects Trust over Time. Proceedings of the 38th Hawaii International Conference on System Sciences, 1-10. http://dx.doi.org/10.1109/HICSS.2005.398

Sillence, E., \& Briggs, P. (2007). Please Advise: Using the Internet for Health and Financial Advice. Computers in Human Behavior, 23, 727-748. http://dx.doi.org/10.1016/j.chb.2004.11.006

Singh, J., \& Sirdeshmukh, D. (2000). Agency and Trust Mechanisms in Consumer Satisfaction and Loyalty Judgments. Journal of Academy of Marketing Science, 28(11), 150-167. http://dx.doi.org/10.1177/0092070300281014

Teo, S. H. T. (2002). Attitudes toward Online Shopping and the Internet. Behaviour \& Information Technology, 21(4), 259-271. http://dx.doi.org/10.1080/0144929021000018342

Tiwana, A. B. (1998). Interdependency Factors Influencing the World Wide Web as a Channel of Interactive Marketing. Journal of Retailing and Consumer Service, 5(4), 245-253. http://dx.doi.org/10.1016/S0969-6989(97)00038-6

Vijayasarathy, L. R., \& Jones, J. M. (2000). Print and Internet Catalog Shopping: Assessing Attitudes and Intentions. Internet Research, 10(3), 191-202. http://dx.doi.org/10.1108/10662240010331948

Wang, Y. D., \& Emurian, H. H. (2005). An Overview of Online Trust: Concepts, Elements, and Implications. Computers in Human Behavior, 21, 105-125. http://dx.doi.org/10.1016/j.chb.2003.11.008

Wang, Y. D., \& Emurian, H. H. (2005). Trust in E-Commerce: Consideration of Interface Design Factors. Journal of Electronic Commerce in Organizations, 3(4), 42-60. http://dx.doi.org/10.4018/jeco.2005100103

Yoon, S. J. (2002). The Antecedents and Consequences of Trust in Online-Purchase Decisions. Journal of 
Interactive marketing, 16(2), 47-63. http://dx.doi.org/10.1002/dir.10008

Zeithaml, V.A., Berry, L.L., \& Parasuraman, A. (1996). The Behavioral Consequences of Service Quality. Journal of Marketing, 60(2), 31-46. Retrieved from http:/www.jstor.org/stable/1251929 